\title{
The Significant and Profound Impacts of Chou's Pseudo Amino Acid Composition or PseAAC
}

\section{Kuo-Chen Chou}

Gordon Life Science Institute, Boston, MA, USA

Correspondence to: Kuo-Chen Chou, kcchou@gordonlifescience.org, kcchou38@gmail.com

Keywords: Pseudo Amino Acid Composition, PseAAC, Significant Impacts, Profound Impacts

Received: September 2, $2020 \quad$ Accepted: September 12, $2020 \quad$ Published: September 15, 2020

Copyright $\odot 2020$ by author(s) and Scientific Research Publishing Inc.

This work is licensed under the Creative Commons Attribution International License (CC BY 4.0).

http://creativecommons.org/licenses/by/4.0/

(c) (i) Open Access

\section{ABSTRACT}

In this short review paper, the significant and profound impacts of the Pseudo Amino Acid Composition or PseAAC have been briefly presented with crystal clear convincingness.

The "pseudo amino acid composition" [1] and "PseAAC" [2] were originally introduced by KuoChen Chou in 2001 and 2005, respectively, to represent protein samples for improving protein subcellular localization prediction and membrane protein type prediction (see, e.g., [3-33]).

However, beyond the aforementioned purpose, their impacts to many other fields are both significantly and profoundly as well (see, e.g., [34-161]).

\section{CONFLICTS OF INTEREST}

The author declares no conflicts of interest regarding the publication of this paper.

\section{REFERENCES}

1. Chou, K.C. (2001) Prediction of Protein Cellular Attributes Using Pseudo Amino Acid Composition. PROTEINS: Structure, Function, and Genetics, 43, 246-255. (Erratum: Ibid., 2001, Vol. 44, 60) https://doi.org/10.1002/prot.1035

2. Chou, K.C. (2005) Using Amphiphilic Pseudo Amino Acid Composition to Predict Enzyme Subfamily Classes. Bioinformatics, 21, 10-19. https://doi.org/10.1093/bioinformatics/bth466

3. Shen, H.B. and Chou, K.C. (2005) Predicting Protein Subnuclear Location with Optimized Evidence-Theoretic K-Nearest Classifier and Pseudo Amino Acid Composition. Biochemical and Biophysical Research Communications (BBRC), 337, 752-756. https://doi.org/10.1016/j.bbrc.2005.09.117

4. Shen, H.B., Yang, J., Liu, X.J. and Chou, K.C. (2005) Using Supervised Fuzzy Clustering to Predict Protein Structural Classes. Biochemical and Biophysical Research Communications (BBRC), 334, 577-581. https://doi.org/10.1016/j.bbrc.2005.06.128

5. Chou, K.C. and Shen, H.B. (2006) Predicting Protein Subcellular Location by Fusing Multiple Classifiers. Jour- 
nal of Cellular Biochemistry, 99, 517-527. https://doi.org/10.1002/jcb.20879

6. Chou, K.C. and Shen, H.B. (2006) Hum-PLoc: A Novel Ensemble Classifier for Predicting Human Protein Subcellular Localization. Biochemical and Biophysical Research Communications (BBRC), 347, 150-157. https://doi.org/10.1016/j.bbrc.2006.06.059

7. Chou, K.C. and Shen, H.B. (2006) Predicting Eukaryotic Protein Subcellular Location by Fusing Optimized Evidence-Theoretic K-Nearest Neighbor Classifiers. Journal of Proteome Research, 5, 1888-1897. https://doi.org/10.1021/pr060167c

8. Chou, K.C. and Shen, H.B. (2006) Addendum to "Hum-PLoc: A Novel Ensemble Classifier for Predicting Human Protein Subcellular Localization". Biochemical and Biophysical Research Communications (BBRC), 348, 1479. https://doi.org/10.1016/j.bbrc.2006.08.030

9. Shen, H.B., Yang, J. and Chou, K.C. (2006) Fuzzy KNN for Predicting Membrane Protein Types from Pseudo Amino Acid Composition. Journal of Theoretical Biology, 240, 9-13. https://doi.org/10.1016/j.jtbi.2005.08.016

10. Chou, K.C. and Shen, H.B. (2007) Euk-mPLoc: A Fusion Classifier for Large-Scale Eukaryotic Protein Subcellular Location Prediction by Incorporating Multiple Sites. Journal of Proteome Research, 6, 1728-1734. https://doi.org/10.1021/pr060635i

11. Chou, K.C. and Shen, H.B. (2007) Signal-CF: A Subsite-Coupled and Window-Fusing Approach for Predicting Signal Peptides. Biochemical and Biophysical Research Communications (BBRC), 357, 633-640.

https://doi.org/10.1016/j.bbrc.2007.03.162

12. Chou, K.C. and Shen, H.B. (2007) MemType-2L: A Web Server for Predicting Membrane Proteins and Their Types by Incorporating Evolution Information through Pse-PSSM. Biochemical and Biophysical Research Communications (BBRC), 360, 339-345. https://doi.org/10.1016/j.bbrc.2007.06.027

13. Chou, K.C. and Shen, H.B. (2007) Recent Progresses in Protein Subcellular Location Prediction. Analytical Biochemistry, 370, 1-16. https://doi.org/10.1016/j.ab.2007.07.006

14. Liu, D.Q., Liu, H., Shen, H.B., Yang, J. and Chou, K.C. (2007) Predicting Secretory Protein Signal Sequence Cleavage Sites by Fusing the Marks of Global Alignments. Amino Acids, 32, 493-496.

https://doi.org/10.1007/s00726-006-0466-Z

15. Shen, H.B. and Chou, K.C. (2007) Using Ensemble Classifier to Identify Membrane Protein Types. Amino Acids, 32, 483-488. https://doi.org/10.1007/s00726-006-0439-2

16. Shen, H.B. and Chou, K.C. (2007) Gpos-PLoc: An Ensemble Classifier for Predicting Subcellular Localization of Gram-Positive Bacterial Proteins. Protein Engineering, Design, and Selection, 20, 39-46.

https://doi.org/10.1093/protein/gzl053

17. Shen, H.B. and Chou, K.C. (2007) EzyPred: A Top-Down Approach for Predicting Enzyme Functional Classes and Subclasses. Biochemical and Biophysical Research Communications (BBRC), 364, 53-59. https://doi.org/10.1016/j.bbrc.2007.09.098

18. Shen, H.B. and Chou, K.C. (2007) Nuc-PLoc: A New Web-Server for Predicting Protein Subnuclear Localization by Fusing PseAA Composition and PsePSSM. Protein Engineering, Design \& Selection, 20, 561-567. https://doi.org/10.1093/protein/gzm057

19. Shen, H.B., Yang, J. and Chou, K.C. (2007) Review: Methodology Development for Predicting Subcellular Localization and Other Attributes of Proteins. Expert Review of Proteomics, 4, 453-463. https://doi.org/10.1586/14789450.4.4.453

20. Chou, K.C. and Shen, H.B. (2008) Cell-PLoc: A Package of Web Servers for Predicting Subcellular Localization of Proteins in Various Organisms. Nature Protocols, 3, 153-162. https://doi.org/10.1038/nprot.2007.494

21. Chou, K.C. and Shen, H.B. (2008) ProtIdent: A Web Server for Identifying Proteases and Their Types by Fusing 
Functional Domain and Sequential Evolution Information. Biochemical and Biophysical Research Communications (BBRC), 376, 321-325. https://doi.org/10.1016/j.bbrc.2008.08.125

22. Shen, H.B. and Chou, K.C. (2008) PseAAC: A Flexible Web-Server for Generating Various Kinds of Protein Pseudo Amino Acid Composition. Analytical Biochemistry, 373, 386-388.

https://doi.org/10.1016/j.ab.2007.10.012

23. Shen, H.B. and Chou, K.C. (2008) HIVcleave: A Web-Server for Predicting HIV Protease Cleavage Sites in Proteins. Analytical Biochemistry, 375, 388-390. https://doi.org/10.1016/j.ab.2008.01.012

24. Wang, T., Yang, J., Shen, H.B. and Chou, K.C. (2008) Predicting Membrane Protein Types by the LLDA Algorithm. Protein \& Peptide Letters, 15, 915-921. https://doi.org/10.2174/092986608785849308

25. Chou, K.C. and Shen, H.B. (2009) Recent Advances in Developing Web-Servers for Predicting Protein Attributes. Natural Science, 1, 63-92. https://doi.org/10.4236/ns.2009.12011

26. Chou, K.C., Wei, D.Q., Du, Q.S., Sirois, S., Shen, H.B. and Zhong, W.Z. (2009) Study of Inhibitors against SARS Coronavirus by Computational Approaches. In: Lendeckel, U. and Hooper, N.M., Eds., Proteases in Biology and Disease: Viral Proteases and Antiviral Protease Inhibitor Therapy, Springer Science, Media B.V., Berlin, 1-23. https://doi.org/10.1007/978-90-481-2348-3_1

27. Shen, H.B. and Chou, K.C. (2009) Predicting Protein Fold Pattern with Functional Domain and Sequential Evolution Information. Journal of Theoretical Biology, 256, 441-446. https://doi.org/10.1016/j.jtbi.2008.10.007

28. Shen, H.B. and Chou, K.C. (2009) Identification of Proteases and Their Types. Analytical Biochemistry, 385, 153-160. https://doi.org/10.1016/j.ab.2008.10.020

29. Shen, H.B. and Chou, K.C. (2009) A Top-Down Approach to Enhance the Power of Predicting Human Protein Subcellular Localization: Hum-mPLoc 2.0. Analytical Biochemistry, 394, 269-274. https://doi.org/10.1016/j.ab.2009.07.046

30. Shen, H.B. and Chou, K.C. (2009) Gpos-mPLoc: A Top-Down Approach to Improve the Quality of Predicting Subcellular Localization of Gram-Positive Bacterial Proteins. Protein \& Peptide Letters, 16, 1478-1484. https://doi.org/10.2174/092986609789839322

31. Shen, H.B., Wang, J.F., Yao, L.X., Yang, J. and Chou, K.C. (2009) Recent Progress of Bioinformatics in Membrane Protein Structural Studies. In: Alterovitz, G., Benson, R. and Ramoni, M.F., Eds., Automation in Proteomics and Genomics. An Engineering Case-Based Approach (Harvard-MIT Interdisciplinary Special Studies Courses), Chap. 12, John Wiley \& Sons, Ltd., West Sussex, 293-308.

https://doi.org/10.1002/9780470741191.ch12

32. Chou, K.C. and Shen, H.B. (2010) Cell-PLoc 2.0: An Improved Package of Web-Servers for Predicting Subcellular Localization of Proteins in Various Organisms. Natural Science, 2, 1090-1103.

https://doi.org/10.4236/ns.2010.210136

33. Shen, H.B. and Chou, K.C. (2010) Gneg-mPLoc: A Top-Down Strategy to Enhance the Quality of Predicting Subcellular Localization of Gram-Negative Bacterial Proteins. Journal of Theoretical Biology, 264, 326-333. https://doi.org/10.1016/j.jtbi.2010.01.018

34. Ding, Y.S. and Zhang, T.L. (2008) Using Chou's Pseudo Amino Acid Composition to Predict Subcellular Localization of Apoptosis Proteins: An Approach with Immune Genetic Algorithm-Based Ensemble Classifier. Pattern Recognition Letters, 29, 1887-1892. https://doi.org/10.1016/j.patrec.2008.06.007

35. Fang, Y., Guo, Y., Feng, Y. and Li, M. (2008) Predicting DNA-Binding Proteins: Approached from Chou's Pseudo Amino Acid Composition and Other Specific Sequence Features. Amino Acids, 34, 103-109. https://doi.org/10.1007/s00726-007-0568-2

36. Jiang, X., Wei, R., Zhang, T.L. and Gu, Q. (2008) Using the Concept of Chou's Pseudo Amino Acid Composi- 
tion to Predict Apoptosis Proteins Subcellular Location: An Approach by Approximate Entropy. Protein \& Peptide Letters, 15, 392-396. https://doi.org/10.2174/092986608784246443

37. Jiang, X., Wei, R., Zhao, Y. and Zhang, T. (2008) Using Chou's Pseudo Amino Acid Composition Based on Approximate Entropy and an Ensemble of Adaboost Classifiers to Predict Protein Subnuclear Location. Amino Acids, 34, 669-675. https://doi.org/10.1007/s00726-008-0034-9

38. Li, F.M. and Li, Q.Z. (2008) Predicting Protein Subcellular Location Using Chou's Pseudo Amino Acid Composition and Improved Hybrid Approach. Protein \& Peptide Letters, 15, 612-616. https://doi.org/10.2174/092986608784966930

39. Lin, H. (2008) The Modified Mahalanobis Discriminant for Predicting Outer Membrane Proteins by Using Chou's Pseudo Amino Acid Composition. Journal of Theoretical Biology, 252, 350-356. https://doi.org/10.1016/j.jtbi.2008.02.004

40. Lin, H., Ding, H., Guo, F.B., Zhang, A.Y. and Huang, J. (2008) Predicting Subcellular Localization of Mycobacterial Proteins by Using Chou's Pseudo Amino Acid Composition. Protein \& Peptide Letters, 15, 739-744. https://doi.org/10.2174/092986608785133681

41. Nanni, L. and Lumini, A. (2008) Genetic Programming for Creating Chou's Pseudo Amino Acid Based Features for Submitochondria Localization. Amino Acids, 34, 653-660. https://doi.org/10.1007/s00726-007-0018-1

42. Zhang, G.Y., Li, H.C., Gao, J.Q. and Fang, B.S. (2008) Predicting Lipase Types by Improved Chou's Pseudo Amino Acid Composition. Protein \& Peptide Letters, 15, 1132-1137. https://doi.org/10.2174/092986608786071184

43. Zhang, S.W., Chen, W., Yang, F. and Pan, Q. (2008) Using Chou's Pseudo Amino Acid Composition to Predict Protein Quaternary Structure: A Sequence-Segmented PseAAC Approach. Amino Acids, 35, 591-598. https://doi.org/10.1007/s00726-008-0086-X

44. Zhang, S.W., Zhang, Y.L., Yang, H.F., Zhao, C.H. and Pan, Q. (2008) Using the Concept of Chou's Pseudo Amino Acid Composition to Predict Protein Subcellular Localization: An Approach by Incorporating Evolutionary Information and Von Neumann Entropies. Amino Acids, 34, 565-572.

https://doi.org/10.1007/s00726-007-0010-9

45. Chen, C., Chen, L., Zou, X. and Cai, P. (2009) Prediction of Protein Secondary Structure Content by Using the Concept of Chou's Pseudo Amino Acid Composition and Support Vector Machine. Protein \& Peptide Letters, 16, 27-31. https://doi.org/10.2174/092986609787049420

46. Georgiou, D.N., Karakasidis, T.E., Nieto, J.J. and Torres, A. (2009) Use of Fuzzy Clustering Technique and Matrices to Classify Amino Acids and Its Impact to Chou's Pseudo Amino Acid Composition. Journal of Theoretical Biology, 257, 17-26. https://doi.org/10.1016/j.jtbi.2008.11.003

47. Li, Z.C., Zhou, X.B., Dai, Z. and Zou, X.Y. (2009) Prediction of Protein Structural Classes by Chou's Pseudo Amino Acid Composition: Approached Using Continuous Wavelet Transform and Principal Component Analysis. Amino Acids, 37, 415-425. https://doi.org/10.1007/s00726-008-0170-2

48. Lin, H., Wang, H., Ding, H., Chen, Y.L. and Li, Q.Z. (2009) Prediction of Subcellular Localization of Apoptosis Protein Using Chou's Pseudo Amino Acid Composition. Acta Biotheoretica, 57, 321-330.

https://doi.org/10.1007/s10441-008-9067-4

49. Qiu, J.D., Huang, J.H., Liang, R.P. and Lu, X.Q. (2009) Prediction of G-Protein-Coupled Receptor Classes Based on the Concept of Chou's Pseudo Amino Acid Composition: An Approach from Discrete Wavelet Transform. Analytical Biochemistry, 390, 68-73. https://doi.org/10.1016/j.ab.2009.04.009

50. Zeng, Y.H., Guo, Y.Z., Xiao, R.Q., Yang, L., Yu, L.Z. and Li, M.L. (2009) Using the Augmented Chou's Pseudo Amino Acid Composition for Predicting Protein Submitochondria Locations Based on Auto Covariance Approach. Journal of Theoretical Biology, 259, 366-372. https://doi.org/10.1016/j.jtbi.2009.03.028 
51. Esmaeili, M., Mohabatkar, H. and Mohsenzadeh, S. (2010) Using the Concept of Chou's Pseudo Amino Acid Composition for Risk Type Prediction of Human Papillomaviruses. Journal of Theoretical Biology, 263, 203-209. https://doi.org/10.1016/j.jtbi.2009.11.016

52. Gu, Q., Ding, Y.S. and Zhang, T.L. (2010) Prediction of G-Protein-Coupled Receptor Classes in Low Homology Using Chou's Pseudo Amino Acid Composition with Approximate Entropy and Hydrophobicity Patterns. Protein \& Peptide Letters, 17, 559-567. https://doi.org/10.2174/092986610791112693

53. Mohabatkar, H. (2010) Prediction of Cyclin Proteins Using Chou's Pseudo Amino Acid Composition. Protein \& Peptide Letters, 17, 1207-1214. https://doi.org/10.2174/092986610792231564

54. Qiu, J.D., Huang, J.H., Shi, S.P. and Liang, R.P. (2010) Using the Concept of Chou's Pseudo Amino Acid Composition to Predict Enzyme Family Classes: An Approach with Support Vector Machine Based on Discrete Wavelet Transform. Protein \& Peptide Letters, 17, 715-722. https://doi.org/10.2174/092986610791190372

55. Sahu, S.S. and Panda, G. (2010) A Novel Feature Representation Method Based on Chou's Pseudo Amino Acid Composition for Protein Structural Class Prediction. Computational Biology and Chemistry, 34, 320-327. https://doi.org/10.1016/j.compbiolchem.2010.09.002

56. Yu, L., Guo, Y., Li, Y., Li, G., Li, M., Luo, J., Xiong, W. and Qin, W. (2010) SecretP: Identifying Bacterial Secreted Proteins by Fusing New Features into Chou's Pseudo Amino Acid Composition. Journal of Theoretical Biology, 267, 1-6. https://doi.org/10.1016/j.jtbi.2010.08.001

57. Guo, J., Rao, N., Li, G., Yang, Y. and Wang, G. (2011) Predicting Protein Folding Rates Using the Concept of Chou's Pseudo Amino Acid Composition. Journal of Computational Chemistry, 32, 1612-1617. https://doi.org/10.1002/jcc.21740

58. Lin, J. and Wang, Y. (2011) Using a Novel AdaBoost Algorithm and Chou's Pseudo Amino Acid Composition for Predicting Protein Subcellular Localization. Protein \& Peptide Letters, 18, 1219-1225. https://doi.org/10.2174/092986611797642797

59. Lin, J., Wang, Y. and Xu, X. (2011) A Novel Ensemble and Composite Approach for Classifying Proteins Based on Chou's Pseudo Amino Acid Composition. African Journal of Biotechnology, 10, 16963-16968.

https://doi.org/10.5897/AJB11.429

60. Mohabatkar, H., Mohammad Beigi, M. and Esmaeili, A. (2011) Prediction of GABA(A) Receptor Proteins Using the Concept of Chou's Pseudo Amino Acid Composition and Support Vector Machine. Journal of Theoretical Biology, 281, 18-23. https://doi.org/10.1016/j.jtbi.2011.04.017

61. Mohammad, B.M., Behjati, M. and Mohabatkar, H. (2011) Prediction of Metalloproteinase Family Based on the Concept of Chou's Pseudo Amino Acid Composition Using a Machine Learning Approach. Journal of Structural and Functional Genomics, 12, 191-197. https://doi.org/10.1007/s10969-011-9120-4

62. Qiu, J.D., Suo, S.B., Sun, X.Y., Shi, S.P. and Liang, R.P. (2011) OligoPred: A Web-Server for Predicting Homo-Oligomeric Proteins by Incorporating Discrete Wavelet Transform into Chou's Pseudo Amino Acid Composition. Journal of Molecular Graphics \& Modelling, 30, 129-134. https://doi.org/10.1016/j.jmgm.2011.06.014

63. Zou, D., He, Z., He, J. and Xia, Y. (2011) Supersecondary Structure Prediction Using Chou's Pseudo Amino Acid Composition. Journal of Computational Chemistry, 32, 271-278. https://doi.org/10.1002/jcc.21616

64. Cao, J.Z., Liu, W.Q. and Gu, H. (2012) Predicting Viral Protein Subcellular Localization with Chou's Pseudo Amino Acid Composition and Imbalance-Weighted Multi-Label K-Nearest Neighbor Algorithm. Protein and Peptide Letters, 19, 1163-1169. https://doi.org/10.2174/092986612803216999

65. Chen, C., Shen, Z.B. and Zou, X.Y. (2012) Dual-Layer Wavelet SVM for Predicting Protein Structural Class via the General Form of Chou's Pseudo Amino Acid Composition. Protein \& Peptide Letters, 19, 422-429. https://doi.org/10.2174/092986612799789332

66. Du, P., Wang, X., Xu, C. and Gao, Y. (2012) PseAAC-Builder: A Cross-Platform Stand-Alone Program for Ge- 
nerating Various Special Chou’s Pseudo Amino Acid Compositions. Analytical Biochemistry, 425, 117-119. https://doi.org/10.1016/j.ab.2012.03.015

67. Fan, G.L. and Li, Q.Z. (2012) Predict Mycobacterial Proteins Subcellular Locations by Incorporating PseudoAverage Chemical Shift into the General Form of Chou's Pseudo Amino Acid Composition. Journal of Theoretical Biology, 304, 88-95. https://doi.org/10.1016/j.jtbi.2012.03.017

68. Fan, G.L. and Li, Q.Z. (2012) Predicting Protein Submitochondria Locations by Combining Different Descriptors into the General Form of Chou's Pseudo Amino Acid Composition. Amino Acids, 43, 545-555. https://doi.org/10.1007/s00726-011-1143-4

69. Li, L.Q., Zhang, Y., Zou, L.Y., Zhou, Y. and Zheng, X.Q. (2012) Prediction of Protein Subcellular Multi-Localization Based on the General form of Chou's Pseudo Amino Acid Composition. Protein \& Peptide Letters, 19, 375-387. https://doi.org/10.2174/092986612799789369

70. Liu, L., Hu, X.Z., Liu, X.X., Wang, Y. and Li, S.B. (2012) Predicting Protein Fold Types by the General Form of Chou's Pseudo Amino Acid Composition: Approached from Optimal Feature Extractions. Protein \& Peptide Letters, 19, 439-449. https://doi.org/10.2174/092986612799789378

71. Nanni, L., Brahnam, S. and Lumini, A. (2012) Wavelet Images and Chou's Pseudo Amino Acid Composition for Protein Classification. Amino Acids, 43, 657-665. https://doi.org/10.1007/s00726-011-1114-9

72. Nanni, L., Lumini, A., Gupta, D. and Garg, A. (2012) Identifying Bacterial Virulent Proteins by Fusing a Set of Classifiers Based on Variants of Chou's Pseudo Amino Acid Composition and on Evolutionary Information. IEEE-ACM Transaction on Computational Biology and Bioinformatics, 9, 467-475. https://doi.org/10.1109/TCBB.2011.117

73. Niu, X.H., Hu, X.H., Shi, F. and Xia, J.B. (2012) Predicting Protein Solubility by the General Form of Chou's Pseudo Amino Acid Composition: Approached from Chaos Game Representation and Fractal Dimension. Protein \& Peptide Letters, 19, 940-948. https://doi.org/10.2174/092986612802084492

74. Ren, L.Y., Zhang, Y.S. and Gutman, I. (2012) Predicting the Classification of Transcription Factors by Incorporating their Binding Site Properties into a Novel Mode of Chou's Pseudo Amino Acid Composition. Protein \& Peptide Letters, 19, 1170-1176. https://doi.org/10.2174/092986612803217088

75. Zhao, X.W., Ma, Z.Q. and Yin, M.H. (2012) Predicting Protein-Protein Interactions by Combing Various Sequence-Derived Features into the General Form of Chou's Pseudo Amino Acid Composition. Protein \& Peptide Letters, 19, 492-500. https://doi.org/10.2174/092986612800191080

76. Zia-ur-Rehman and Khan, A. (2012) Identifying GPCRs and Their Types with Chou's Pseudo Amino Acid Composition: An Approach from Multi-Scale Energy Representation and Position Specific Scoring Matrix. Protein \& Peptide Letters, 19, 890-903. https://doi.org/10.2174/092986612801619589

77. Chen, Y.K. and Li, K.B. (2013) Predicting Membrane Protein Types by Incorporating Protein Topology, Domains, Signal Peptides, and Physicochemical Properties into the General Form of Chou's Pseudo Amino Acid Composition. Journal of Theoretical Biology, 318, 1-12. https://doi.org/10.1016/j.jtbi.2012.10.033

78. Fan, G.L. and Li, Q.Z. (2013) Discriminating Bioluminescent Proteins by Incorporating Average Chemical Shift and Evolutionary Information into the General Form of Chou's Pseudo Amino Acid Composition. Journal of Theoretical Biology, 334, 45-51. https://doi.org/10.1016/j.jtbi.2013.06.003

79. Georgiou, D.N., Karakasidis, T.E. and Megaritis, A.C. (2013) A Short Survey on Genetic Sequences, Chou's Pseudo Amino Acid Composition and Its Combination with Fuzzy Set Theory. The Open Bioinformatics Journal, 7, 41-48. https://doi.org/10.2174/1875036201307010041

80. Gupta, M.K., Niyogi, R. and Misra, M. (2013) An Alignment-Free Method to Find Similarity among Protein Sequences via the General Form of Chou's Pseudo Amino Acid Composition. SAR and QSAR in Environmental 
Research, 24, 597-609. https://doi.org/10.1080/1062936X.2013.773378

81. Huang, C. and Yuan, J. (2013) Using Radial Basis Function on the General Form of Chou's Pseudo Amino Acid Composition and PSSM to Predict Subcellular Locations of Proteins with Both Single and Multiple Sites. Biosystems, 113, 50-57. https://doi.org/10.1016/j.biosystems.2013.04.005

82. Huang, C. and Yuan, J.Q. (2013) A Multilabel Model Based on Chou's Pseudo Amino Acid Composition for Identifying Membrane Proteins with Both Single and Multiple Functional Types. The Journal of Membrane Biology, 246, 327-334. https://doi.org/10.1007/s00232-013-9536-9

83. Huang, C. and Yuan, J.Q. (2013) Predicting Protein Subchloroplast Locations with Both Single and Multiple Sites via Three Different Modes of Chou's Pseudo Amino Acid Compositions. Journal of Theoretical Biology, 335, 205-212. https://doi.org/10.1016/j.jtbi.2013.06.034

84. Khosravian, M., Faramarzi, F.K., Beigi, M.M., Behbahani, M. and Mohabatkar, H. (2013) Predicting Antibacterial Peptides by the Concept of Chou's Pseudo Amino Acid Composition and Machine Learning Methods. Protein \& Peptide Letters, 20, 180-186. https://doi.org/10.2174/092986613804725307

85. Lin, H., Ding, C., Yuan, L.-F., Chen, W., Ding, H., Li, Z.-Q., Guo, F.-B., Huang, J. and Rao, N. (2013) Predicting Subchloroplast Locations of Proteins Based on the General Form of Chou's Pseudo Amino Acid Composition: Approached from Optimal Tripeptide Composition. International Journal of Biomethmatics, 6, Article ID: 1350003. https://doi.org/10.1142/S1793524513500034

86. Liu, B., Wang, X., Zou, Q., Dong, Q. and Chen, Q. (2013) Protein Remote Homology Detection by Combining Chou's Pseudo Amino Acid Composition and Profile-Based Protein Representation. Molecular Informatics, 32, 775-782. https://doi.org/10.1002/minf.201300084

87. Mohabatkar, H., Beigi, M.M., Abdolahi, K. and Mohsenzadeh, S. (2013) Prediction of Allergenic Proteins by Means of the Concept of Chou's Pseudo Amino Acid Composition and a Machine Learning Approach. Medicinal Chemistry, 9, 133-137. https://doi.org/10.2174/157340613804488341

88. Qin, Y.F., Zheng, L. and Huang, J. (2013) Locating Apoptosis Proteins by Incorporating the Signal Peptide Cleavage Sites into the General Form of Chou's Pseudo Amino Acid Composition. International Journal of Quantum Chemistry, 113, 1660-1667. https://doi.org/10.1002/qua.24383

89. Sarangi, A.N., Lohani, M. and Aggarwal, R. (2013) Prediction of Essential Proteins in Prokaryotes by Incorporating Various Physico-Chemical Features into the General Form of Chou's Pseudo Amino Acid Composition. Protein \& Peptide Letters, 20, 781-795. https://doi.org/10.2174/0929866511320070008

90. Wan, S., Mak, M.W. and Kung, S.Y. (2013) GOASVM: A Subcellular Location Predictor by Incorporating Term-Frequency Gene Ontology into the General Form of Chou's Pseudo Amino Acid Composition. Journal of Theoretical Biology, 323, 40-48. https://doi.org/10.1016/j.jtbi.2013.01.012

91. Wang, X., Li, G.Z. and Lu, W.C. (2013) Virus-ECC-mPLoc: A Multi-Label Predictor for Predicting the Subcellular Localization of Virus Proteins with Both Single and Multiple Sites Based on a General Form of Chou's Pseudo Amino Acid Composition. Protein \& Peptide Letters, 20, 309-317. https://doi.org/10.2174/092986613804910608

92. Niu, X.H., et al. (2013) Using the Concept of Chou's Pseudo Amino Acid Composition to Predict Protein Solubility: An Approach with Entropies in Information Theory. Journal of Theoretical Biology, 332, 211-217. https://doi.org/10.1016/j.jtbi.2013.03.010

93. Du, P., Gu, S. and Jiao, Y. (2014) PseAAC-General: Fast Building Various Modes of General Form of Chou's Pseudo Amino Acid Composition for Large-Scale Protein Datasets. International Journal of Molecular Sciences, 15, 3495-3506. https://doi.org/10.3390/ijms15033495

94. Hajisharifi, Z., Piryaiee, M., Mohammad Beigi, M., Behbahani, M. and Mohabatkar, H. (2014) Predicting Anticancer Peptides with Chou's Pseudo Amino Acid Composition and Investigating Their Mutagenicity via Ames 
Test. Journal of Theoretical Biology, 341, 34-40. https://doi.org/10.1016/j.jtbi.2013.08.037

95. Jia, C., Lin, X. and Wang, Z. (2014) Prediction of Protein S-Nitrosylation Sites Based on Adapted Normal Distribution Bi-Profile Bayes and Chou's Pseudo Amino Acid Composition. International Journal of Molecular Sciences, 15, 10410-10423. https://doi.org/10.3390/ijms150610410

96. Kong, L., Zhang, L. and Lv, J. (2014) Accurate Prediction of Protein Structural Classes by Incorporating Predicted Secondary Structure Information into the General Form of Chou's Pseudo Amino Acid Composition. Journal of Theoretical Biology, 344, 12-18. https://doi.org/10.1016/j.jtbi.2013.11.021

97. Nanni, L., Brahnam, S. and Lumini, A. (2014) Prediction of Protein Structure Classes by Incorporating Different Protein Descriptors into General Chou's Pseudo Amino Acid Composition. Journal of Theoretical Biology, 360, 109-116. https://doi.org/10.1016/j.jtbi.2014.07.003

98. Zhang, J., Sun, P., Zhao, X. and Ma, Z. (2014) PECM: Prediction of Extracellular Matrix Proteins Using the Concept of Chou's Pseudo Amino Acid Composition. Journal of Theoretical Biology, 363, 412-418. https://doi.org/10.1016/j.jtbi.2014.08.002

99. Zhang, L., Zhao, X. and Kong, L. (2014) Predict Protein Structural Class for Low-Similarity Sequences by Evolutionary Difference Information into the General Form of Chou's Pseudo Amino Acid Composition. Journal of Theoretical Biology, 355, 105-110. https://doi.org/10.1016/j.jtbi.2014.04.008

100. Zuo, Y.C., Peng, Y., Liu, L., Chen, W., Yang, L. and Fan, G.L. (2014) Predicting Peroxidase Subcellular Location by Hybridizing Different Descriptors of Chou's Pseudo Amino Acid Patterns. Analytical Biochemistry, 458, 14-19. https://doi.org/10.1016/j.ab.2014.04.032

101. Ali, F. and Hayat, M. (2015) Classification of Membrane Protein Types Using Voting Feature Interval in Combination with Chou's Pseudo Amino Acid Composition. Journal of Theoretical Biology, 384, 78-83. https://doi.org/10.1016/j.jtbi.2015.07.034

102. Fan, G.L., Zhang, X.Y., Liu, Y.L., Nang, Y. and Wang, H. (2015) DSPMP: Discriminating Secretory Proteins of Malaria Parasite by Hybridizing Different Descriptors of Chou's Pseudo Amino Acid Patterns. Journal of Computational Chemistry, 36, 2317-2327. https://doi.org/10.1002/jcc.24210

103. Huang, C. and Yuan, J.Q. (2015) Simultaneously Identify Three Different Attributes of Proteins by Fusing Their Three Different Modes of Chou's Pseudo Amino Acid Compositions. Protein \& Peptide Letters, 22, 547-556. https://doi.org/10.2174/0929866522666150209151344

104. Khan, Z.U., Hayat, M. and Khan, M.A. (2015) Discrimination of Acidic and Alkaline Enzyme Using Chou's Pseudo Amino Acid Composition in Conjunction with Probabilistic Neural Network Model. Journal of Theoretical Biology, 365, 197-203. https://doi.org/10.1016/j.jtbi.2014.10.014

105. Kumar, R., Srivastava, A., Kumari, B. and Kumar, M. (2015) Prediction of Beta-Lactamase and Its Class by Chou's Pseudo Amino Acid Composition and Support Vector Machine. Journal of Theoretical Biology, 365, 96-103. https://doi.org/10.1016/j.jtbi.2014.10.008

106. Wang, X., Zhang, W., Zhang, Q. and Li, G.Z. (2015) MultiP-SChlo: Multi-Label Protein Subchloroplast Localization Prediction with Chou's Pseudo Amino Acid Composition and a Novel Multi-Label Classifier. Bioinformatics, 31, 2639-2645. https://doi.org/10.1093/bioinformatics/btv212

107. Jiao, Y.S. and Du, P.F. (2016) Prediction of Golgi-Resident Protein Types Using General Form of Chou's Pseudo Amino Acid Compositions: Approaches with Minimal Redundancy Maximal Relevance Feature Selection. Journal of Theoretical Biology, 402, 38-44. https://doi.org/10.1016/j.jtbi.2016.04.032

108. Tang, H., Chen, W. and Lin, H. (2016) Identification of Immunoglobulins Using Chou's Pseudo Amino Acid Composition with Feature Selection Technique. Molecular BioSystems, 12, 1269-1275. https://doi.org/10.1039/C5MB00883B 
109. Zou, H.L. and Xiao, X. (2016) Predicting the Functional Types of Singleplex and Multiplex Eukaryotic Membrane Proteins via Different Models of Chou's Pseudo Amino Acid Compositions. The Journal of Membrane Biology, 249, 23-29. https://doi.org/10.1007/s00232-015-9830-9

110. Huo, H., Li, T., Wang, S., Lv, Y., Zuo, Y. and Yang, L. (2017) Prediction of Presynaptic and Postsynaptic Neurotoxins by Combining Various Chou's Pseudo Components. Scientific Reports, 7, Article No. 5827. https://doi.org/10.1038/s41598-017-06195-y

111. Rahimi, M., Bakhtiarizadeh, M.R. and Mohammadi-Sangcheshmeh, A. (2017) OOgenesis_Pred: A Sequence-Based Method for Predicting Oogenesis Proteins by Six Different Modes of Chou's Pseudo Amino Acid Composition. Journal of Theoretical Biology, 414, 128-136. https://doi.org/10.1016/j.jtbi.2016.11.028

112. Tripathi, P. and Pandey, P.N. (2017) A Novel Alignment-Free Method to Classify Protein Folding Types by Combining Spectral Graph Clustering with Chou's Pseudo Amino Acid Composition. Journal of Theoretical Biology, 424, 49-54. https://doi.org/10.1016/j.jtbi.2017.04.027

113. Yu, B., Lou, L., Li, S., Zhang, Y., Qiu, W., Wu, X., Wang, M. and Tian, B. (2017) Prediction of Protein Structural Class for Low-Similarity Sequences Using Chou's Pseudo Amino Acid Composition and Wavelet Denoising. Journal of Molecular Graphics and Modelling, 76, 260-273. https://doi.org/10.1016/j.jmgm.2017.07.012

114. Al Maruf, M.A. and Shatabda, S. (2018) iRSpot-SF: Prediction of Recombination Hotspots by Incorporating Sequence Based Features into Chou's Pseudo Components. Genomics, 18, 63-82.

115. Arif, M., Hayat, M. and Jan, Z. (2018) iMem-2LSAAC: A Two-Level Model for Discrimination of Membrane Proteins and Their Types by Extending the Notion of SAAC into Chou's Pseudo Amino Acid Composition. Journal of Theoretical Biology, 442, 11-21. https://doi.org/10.1016/j.jtbi.2018.01.008

116. Cui, X., Yu, Z., Yu, B., Wang, M., Tian, B. and Ma, Q. (2018) UbiSitePred: A Novel Method for Improving the Accuracy of Ubiquitination Sites Prediction by Using LASSO to Select the Optimal Chou's Pseudo Components. Chemometrics and Intelligent Laboratory Systems (CHEMOLAB), 17, 512-538.

117. Mei, J. and Zhao, J. (2018) Prediction of HIV-1 and HIV-2 Proteins by Using Chou's Pseudo Amino Acid Compositions and Different Classifiers. Scientific Reports, 8, Article No. 2359. https://doi.org/10.1038/s41598-018-20819-x

118. Qiu, W., Li, S., Cui, X., Yu, Z., Wang, M., Du, J., Peng, Y. and Yu, B. (2018) Predicting Protein Submitochondrial Locations by Incorporating the Pseudo-Position Specific Scoring Matrix into the General Chou's Pseudo-Amino Acid Composition. Journal of Theoretical Biology, 450, 86-103.

https://doi.org/10.1016/j.jtbi.2018.04.026

119. Zhang, L. and Kong, L. (2018) iRSpot-ADPM: Identify Recombination Spots by Incorporating the Associated Dinucleotide Product Model into Chou's Pseudo Components. Journal of Theoretical Biology, 441, 1-8. https://doi.org/10.1016/j.jtbi.2017.12.025

120. Zhang, S., Yang, K., Lei, Y. and Song, K. (2018) iRSpot-DTS: Predict Recombination Spots by Incorporating the Dinucleotide-Based Spare-Cross Covariance Information into Chou's Pseudo Components. Genomics, 11, 457464.

121. Zhao, W., Wang, L., Zhang, T.X., Zhao, Z.N. and Du, P.F. (2018) A Brief Review on Software Tools in Generating Chou's Pseudo-Factor Representations for All Types of Biological Sequences. Protein \& Peptide Letters, 25, 822-829. https://doi.org/10.2174/0929866525666180905111124

122. Al Maruf, M.A. and Shatabda, S. (2019) iRSpot-SF: Prediction of Recombination Hotspots by Incorporating Sequence Based Features into Chou's Pseudo Components. Genomics, 111, 966-972.

https://doi.org/10.1016/j.ygeno.2018.06.003

123. Nosrati, M., Mohabatkar, H. and Behbahani, M. (2019) Introducing of an Integrated Artificial Neural Network 
and Chou's Pseudo Amino Acid Composition Approach for Computational Epitope-Mapping of CrimeanCongo Haemorrhagic Fever Virus Antigens. International Immunopharmacology, 78, Article ID: 106020. https://doi.org/10.1016/j.intimp.2019.106020

124. Pan, Y., Wang, S., Zhang, Q., Lu, Q., Su, D., Zuo, Y. and Yang, L. (2019) Analysis and Prediction of Animal Toxins by Various Chou's Pseudo Components and Reduced Amino Acid Compositions. Journal of Theoretical Biology, 462, 221-229. https://doi.org/10.1016/j.jtbi.2018.11.010

125. Tahir, M., Tayara, H. and Chong, K.T. (2019) iRNA-PseKNC(2methyl): Identify RNA 2'-O-methylation Sites by Convolution Neural Network and Chou's Pseudo Components. Journal of Theoretical Biology, 465, 1-6. https://doi.org/10.1016/j.jtbi.2018.12.034

126. Tian, B., Wu, X., Chen, C., Qiu, W., Ma, Q. and Yu, B. (2019) Predicting Protein-Protein Interactions by Fusing Various Chou's Pseudo Components and Using Wavelet Denoising Approach. Journal of Theoretical Biology, 462, 329-346. https://doi.org/10.1016/j.jtbi.2018.11.011

127. Zhang, L. and Kong, L. (2019) iRSpot-PDI: Identification of Recombination Spots by Incorporating Dinucleotide Property Diversity Information into Chou’s Pseudo Components. Genomics, 111, 457-464. https://doi.org/10.1016/j.ygeno.2018.03.003

128. Zhang, S., Yang, K., Lei, Y. and Song, K. (2019) iRSpot-DTS: Predict Recombination Spots by Incorporating the Dinucleotide-Based Spare-Cross Covariance Information into Chou's Pseudo Components. Genomics, 111, 17601770. https://doi.org/10.1016/j.ygeno.2018.11.031

129. Nosrati, M., Mohabatkar, H. and Behbahani, M. (2020) Introducing of an Integrated Artificial Neural Network and Chou's Pseudo Amino Acid Composition Approach for Computational Epitope-Mapping of CrimeanCongo Haemorrhagic Fever Virus Antigens. International Immunopharmacology, 78, Article ID: 106020. https://doi.org/10.1016/j.intimp.2019.106020

130. Hayat, M. and Khan, A. (2012) Discriminating Outer Membrane Proteins with Fuzzy K-Nearest Neighbor Algorithms Based on the General Form of Chou's PseAAC. Protein \& Peptide Letters, 19, 411-421. https://doi.org/10.2174/092986612799789387

131. Liao, B., Xiang, Q. and Li, D. (2012) Incorporating Secondary Features into the General form of Chou's PseAAC for Predicting Protein Structural Class. Protein \& Peptide Letters, 19, 1133-1138. https://doi.org/10.2174/092986612803217051

132. Mei, S. (2012) Multi-Kernel Transfer Learning Based on Chou's PseAAC Formulation for Protein Submitochondria Localization. Journal of Theoretical Biology, 293, 121-130. https://doi.org/10.1016/j.jtbi.2011.10.015

133. Mei, S. (2012) Predicting Plant Protein Subcellular Multi-Localization by Chou's PseAAC Formulation Based Multi-Label Homolog Knowledge Transfer Learning. Journal of Theoretical Biology, 310, 80-87. https://doi.org/10.1016/j.jtbi.2012.06.028

134. Qin, Y.F., Wang, C.H., Yu, X.Q., Zhu, J., Li, T. and Zheng, X.Q. (2012) Predicting Protein Structural Class by Incorporating Patterns of Over-Represented k-mers into the General form of Chou's PseAAC. Protein \& Peptide Letters, 19, 388-397. https://doi.org/10.2174/092986612799789350

135. Sun, X.Y., Shi, S.P., Qiu, J.D., Suo, S.B., Huang, S.Y. and Liang, R.P. (2012) Identifying Protein Quaternary Structural Attributes by Incorporating Physicochemical Properties into the General Form of Chou's PseAAC via Discrete Wavelet Transform. Molecular BioSystems, 8, 3178-3184. https://doi.org/10.1039/c2mb25280e

136. Cao, D.S., Xu, Q.S. and Liang, Y.Z. (2013) Propy: A Tool to Generate Various Modes of Chou's PseAAC. Bioinformatics, 29, 960-962. https://doi.org/10.1093/bioinformatics/btt072

137. Chang, T.H., Wu, L.C., Lee, T.Y., Chen, S.P., Huang, H.D. and Horng, J.T. (2013) EuLoc: A Web-Server for Accurately Predict Protein Subcellular Localization in Eukaryotes by Incorporating Various Features of Se- 
quence Segments into the General Form of Chou's PseAAC. Journal of Computer-Aided Molecular Design, 27, 91-103. https://doi.org/10.1007/s10822-012-9628-0

138. Fan, G.-L., Li, Q.-Z. and Zuo, Y.-C. (2013) Predicting Acidic and Alkaline Enzymes by Incorporating the Average Chemical Shift and Gene Ontology Informations into the General Form of Chou's PseAAC. Process Biochemistr, 48, 1048-1053. https://doi.org/10.1016/j.procbio.2013.05.012

139. Pacharawongsakda, E. and Theeramunkong, T. (2013) Predict Subcellular Locations of Singleplex and Multiplex Proteins by Semi-Supervised Learning and Dimension-Reducing General Mode of Chou's PseAAC. IEEE Transactions on Nanobioscience, 12, 311-320. https://doi.org/10.1109/TNB.2013.2272014

140. Xie, H.L., Fu, L. and Nie, X.D. (2013) Using Ensemble SVM to Identify Human GPCRs N-Linked Glycosylation Sites Based on the General Form of Chou's PseAAC. Protein Engineering, Design and Selection, 26, 735-742. https://doi.org/10.1093/protein/gzt042

141. Han, G.S., Yu, Z.G. and Anh, V. (2014) A Two-Stage SVM Method to Predict Membrane Protein Types by Incorporating Amino Acid Classifications and Physicochemical Properties into a General Form of Chou's PseAAC. Journal of Theoretical Biology, 344, 31-39. https://doi.org/10.1016/j.jtbi.2013.11.017

142. Li, L., Yu, S., Xiao, W., Li, Y., Li, M., Huang, L., Zheng, X., Zhou, S. and Yang, H. (2014) Prediction of Bacterial Protein Subcellular Localization by Incorporating Various Features into Chou's PseAAC and a Backward Feature Selection Approach. Biochimie, 104, 100-107. https://doi.org/10.1016/j.biochi.2014.06.001

143. Zhang, J., Zhao, X., Sun, P. and Ma, Z. (2014) PSNO: Predicting Cysteine S-Nitrosylation Sites by Incorporating Various Sequence-Derived Features into the General Form of Chou's PseAAC. International Journal of Molecular Sciences, 15, 11204-11219. https://doi.org/10.3390/ijms150711204

144. Liu, B., Xu, J., Fan, S., Xu, R., Zhou, J. and Wang, X. (2015) PseDNA-Pro: DNA-Binding Protein Identification by Combining Chou's PseAAC and Physicochemical Distance Transformation. Molecular Informatics, 34, 8-17. https://doi.org/10.1002/minf.201400025

145. Mandal, M., Mukhopadhyay, A. and Maulik, U. (2015) Prediction of Protein Subcellular Localization by Incorporating Multiobjective PSO-Based Feature Subset Selection into the General Form of Chou's PseAAC. Medical \& Biological Engineering \& Computing, 53, 331-344. https://doi.org/10.1007/s11517-014-1238-7

146. Sanchez, V., Peinado, A.M., Perez-Cordoba, J.L. and Gomez, A.M. (2015) A New Signal Characterization and Signal-Based Chou's PseAAC Representation of Protein Sequences. Journal of Bioinformatics and Computational Biology, 13, Article ID: 1550024. https://doi.org/10.1142/S0219720015500249

147. Kabir, M. and Hayat, M. (2016) iRSpot-GAEnsC: Identifying Recombination Spots via Ensemble Classifier and Extending the Concept of Chou's PseAAC to Formulate DNA Samples. Molecular Genetics and Genomics, 291, 285-296. https://doi.org/10.1007/s00438-015-1108-5

148. Tahir, M. and Hayat, M. (2016) iNuc-STNC: A Sequence-Based Predictor for Identification of Nucleosome Positioning in Genomes by Extending the Concept of SAAC and Chou's PseAAC. Molecular BioSystems, 12, 2587-2593. https://doi.org/10.1039/C6MB00221H

149. Ju, Z.J. and He, J. (2017) Prediction of Lysine Propionylation Sites Using Biased SVM and Incorporating Four Different Sequence Features into Chou's PseAAC. Journal of Molecular Graphics and Modelling, 76, 356-363. https://doi.org/10.1016/j.jmgm.2017.07.022

150. Yu, B., Li, S., Qiu, W.Y., Chen, C., Chen, R.X., Wang, L., Wang, M.H. and Zhang, Y. (2017) Accurate Prediction of Subcellular Location of Apoptosis Proteins Combining Chou's PseAAC and PsePSSM Based on Wavelet Denoising. Oncotarget, 8, 107640-107665. https://doi.org/10.18632/oncotarget.22585

151. Ahmad, J. and Hayat, M. (2018) MFSC: Multi-Voting Based Feature Selection for Classification of Golgi Proteins by Adopting the General Form of Chou's PseAAC Components. Journal of Theoretical Biology, 463, 99109. https://doi.org/10.1016/j.jtbi.2018.12.017 
152. Akbar, S. and Hayat, M. (2018) iMethyl-STTNC: Identification of N(6)-methyladenosine Sites by Extending the Idea of SAAC into Chou's PseAAC to Formulate RNA Sequences. Journal of Theoretical Biology, 455, 205-211. https://doi.org/10.1016/j.jtbi.2018.07.018

153. Contreras-Torres, E. (2018) Predicting Structural Classes of Proteins by Incorporating Their Global and Local Physicochemical and Conformational Properties into General Chou's PseAAC. Journal of Theoretical Biology, 454, 139-145. https://doi.org/10.1016/j.jtbi.2018.05.033

154. Fu, X., Zhu, W., Liso, B., Cai, L., Peng, L. and Yang, J. (2018) Improved DNA-Binding Protein Identification by Incorporating Evolutionary Information into the Chou's PseAAC. IEEE Access, 18, 43-66.

155. Javed, F. and Hayat, M. (2018) Predicting Subcellular Localizations of Multi-Label Proteins by Incorporating the Sequence Features into Chou's PseAAC. Genomics, 17, 793-821.

156. Mousavizadegan, M. and Mohabatkar, H. (2018) Computational Prediction of Antifungal Peptides via Chou's PseAAC and SVM. Journal of Bioinformatics and Computational Biology, Article ID: 1850016. https://doi.org/10.1142/S0219720018500166

157. Zhang, S. and Li, Y. (2018) Predicting Apoptosis Protein Subcellular Localization by Integrating Auto-Cross Correlation and PSSM into Chou's PseAAC. Journal of Theoretical Biology, 457, 163-169.

https://doi.org/10.1016/j.jtbi.2018.08.042

158. Ahmad, J. and Hayat, M. (2019) MFSC: Multi-Voting Based Feature Selection for Classification of Golgi Proteins by Adopting the General Form of Chou's PseAAC Components. Journal of Theoretical Biology, 463, 99109. https://doi.org/10.1016/j.jtbi.2018.12.017

159. Butt, A.H., Rasool, N. and Khan, Y.D. (2019) Prediction of Antioxidant Proteins by Incorporating Statistical Moments Based Features into Chou's PseAAC. Journal of Theoretical Biology, 473, 1-8. https://doi.org/10.1016/j.jtbi.2019.04.019

160. Javed, F. and Hayat, M. (2019) Predicting Subcellular Localization of Multi-Label Proteins by Incorporating the Sequence Features into Chou's PseAAC. Genomics, 111, 1325-1332. https://doi.org/10.1016/j.ygeno.2018.09.004

161. Tahir, M., Hayat, M. and Khan, S.A. (2019) iNuc-ext-PseTNC: An Efficient Ensemble Model for Identification of Nucleosome Positioning by Extending the Concept of Chou's PseAAC to Pseudo-Tri-Nucleotide Composition. Molecular Genetics and Genomics: MGG, 294, 199-210. https://doi.org/10.1007/s00438-018-1498-2 